\title{
ALTERNATIVES FOR THE EFFICIENT MANAGEMENT OF SOCIAL AND ENVIRONMENTAL COMPONENTS IN HYDROCARBON PROJECTS: TECHNICAL INSTRUMENTS FOR MAKING MANAGEMENT DECISIONS
}

\author{
CLAUDIA L. LONDOÑO CASTAÑEDA \& MÓNICA T. HERRERA \\ University Santo Tomas, Colombia
}

\begin{abstract}
The development of hydrocarbon projects in areas of special interest in the presence of ethnic groups, as well as the possible negative impact on biodiversity and services of strategic ecosystems represents a challenge and an opportunity for the implementation of technical instruments accompanying entrepreneurs and competent authorities in improved social, economic, and environmental management of both positive and negative impacts. This paper presents the results of the construction of a system of indicators to manage both positive and negative impacts on hydrocarbon projects in areas of special interest due to their biodiversity and/or the presence of ethnic groups. The investigation had the active participation of the lawyer and the geologist of MOMPOS Oil and Co., with whom a collaboration agreement was signed in 2015-2016. The main objective of the proposed indicators is to guide decisionmaking regarding the project, identifying the main factors that will compromise the development because they will require a greater investment in compensation issues for biodiversity loss; conflict with armed groups, presence of illicit crops in the territory and prior consultation processes in territories of ethnic groups recognized by law. The proposal of resulting indicators reflects the major management requirements of both business and the various authorities involved in the management of these projects. Particularly in the regions where these projects are advanced, given that the project approach is to orient measures of environmental and social management required in the existing regulatory framework.

Keywords: validation and management of socioeconomic and environmental impacts, ecosystem services, territorial planning and land use and management, ethnic groups.
\end{abstract}

\section{INTRODUCTION}

The development of any exploitation project of mining energy resources in Colombia requires the application for an environmental license that will granted by the National Environmental Licenses Authority (ANLA). In that document, the company presents under a manual proposed by the ANLA, the evaluation of the main impacts; an ecological characterization of the area of interest; the economic valuation of impacts that includes the socioeconomic diagnosis of the area that will be intervened. This diagnosis is accompanied by an Environmental Management Plan PMA, and a compensation proposal for the inhabitants of the area of influence of the project. If the environmental authority grants the license, it must ensure compliance with what agreed in the environmental management plan. In particular, by the specific issues required by law, such as compensation for biodiversity loss and prior consultation processes with ethnic groups. Additionally, variables were included with respect to the exclusion zones such as protected areas, forest reserves of Law 53 and Ramsar Sites, whose shapes are available in the geographical viewers of government entities and environmental NGOs [1].

The present work proposes a series of indicators that allow for the management the impacts before they happen. The framework of the requirements of the law for the environmental license and the implementation of the PMA Environmental Management Plan, as indicated in the "General Methodology for the presentation of Environmental Studies" 
approved by resolution 1503 of 2010, Decree 2041 of 2014 [2]. Additionally, consider: (1) Law 21 of 1991 that regulates prior consultation with ethnic groups, so that these give their consent and establish any compensation that may arise; (2) Law 165 that ratifies the Convention on Biological Diversity; (3) The single regulatory decree 1076 of 2015 on the Ministry of the Environment and Sustainable Development, mainly [1].

For the construction of the proposal, different systems of environmental indicators reviewed to beginning with the "System of Environmental Sustainability Indicators" prepared by the Ministry of the Environment with the technical and financial support of the Economic Commission for Latin America and the Caribbean (CEPAL) and the United Nations Development Program (UNDP) in 2002. The creation of this System of Environmental Indicators, made up of national entities, regional entities, and environmental research institutes, generated a total of twenty-six (26) indicators and four categories (environmental offer, demand, generation, and management of the "outputs" of the economic and social system, and environmental management) under the PER (Pressure-StateResponse) framework [3] . The matrices of Conesa [4] simplified, while Bergere Leopold et al. [5] and Arboleda [6] also revised. Afterwards, interviews conducted with technicians of the companies and environmental authorities in the field, and a workshop with experts facilitated in Bogota with representatives of public and private entities responsible for managing this issue at the local, national, and regional level. In this workshop, experts gave feedback on the proposed indicators as well as the criteria used to assess the impacts.

Indicators are framed in relation to the requirements of management measures, restoration, and compensation in the areas of project influence [7]. Given this, the proposal of resulting indicators reflects the main management requirements of both business and the various authorities involved in the management of these projects in the regions where they are being advanced since the project approach is to orient measures of environmental and social management required in the existing regulatory framework. In a detailed review of the proposed criteria on the conventional methods of the Environmental Impact Evaluation (EIE), the main variables to be considered were drawn out. In view of the complexity of implementing a system that integrates all the requirements of law in due course, a simplified tool is proposed, that will facilitate and guide the decision making of businesses and authorities prior to the occurrence of impacts. This was achieved using real data from a block that currently being explored in an area of importance for biodiversity, ecosystem services, and indigenous communities. Different layers of geographic information were analysed in relation to the coordinates of the block, that were available on various platforms of state entities, the web page of the National Parks System, the Information System of the Humboldt Institute (SIB), among others.

The objective is to minimize the environmental and social impact based on specialized information obtained from reliable secondary sources. This paper presents an overview of the management of hydrocarbon projects with complex territorial dynamics for efficient management in ecology and socio-economic terms.

\subsection{The evolution of hydrocarbons in Colombia and community benefit programs in the areas of direct influence}

The mining and energy sector of Colombia has been considered, by recent governments, as one of the main engines of economic growth. Much of the income needed for the functioning of the state are generated through the royalty regime for this sector. Colombia is the 4th largest producer of crude oil in Latin America, after Venezuela, Mexico, and Brazil (National Hydrocarbons Agency (ANH)) [8]. Production is mainly located in the departments of 
Casanare, Meta, and Arauca, whose share of GDP in recent years has increased considerably according to the indicators and strategies of the Hydrocarbon Sector, 2015. The economic contribution of the oil sector corresponds to approximately $31 \%$ of total revenues in the country, representing approximately $5.5 \%$ of the national gross domestic product (GDP) and about $30 \%$ of Direct Foreign investment (IDR) of Colombia [9].

The relevance of the mining and energy sector as one of the driving forces of the country's development are understood by analysing its share in GDP, which went from $9.7 \%$ in the four-year period 2006-2009 to $11.2 \%$ in the period 2010-2013. Within the mining and energy sector, the hydrocarbons subsector generates the main contribution to GDP, with a participation of $52.3 \%$ of the total contribution of the sector in the years 2010-2013 [10]. In comparison to its contributions with other branches of activities, from 2010 it showed an exponential growth until 2014 where the price of oil falls due to the crisis it faces and this strike in the economy of the country.

The country has faced a crisis in the petroleum industry, specifically in the last two years (2014-2015), with the price of a barrel of crude losing almost 75 percent of its value since the middle of 2014 [11], [12]. The drop in oil prices estimated at between $\$ 20$ US and $\$ 40$ US per barrel when over a year ago oil was trading at \$70 US or \$100 US [13]. The industry also faces frequent economic losses due to attacks on the oil infrastructure, El Niño, the closure of the border with Venezuela, and the devaluation of the exchange rate. Despite this, that costs were reduced in 2015 and production at 5,000 barrels per day increased, reaching 761,000 the equivalent day [14].

A review was conducted of official documents generated by the government such as: the manual for the allocation of compensation for loss of biodiversity [15]; the "Terms of Reference" for the environmental licensing process for the exploration, exploitation, drilling, handling, distribution terminals, and for the construction and operation of refineries [16]. Include the reports from the National Planning Department (DNP) on the social investments of resources generated by the hydrocarbon sector, the "Baseline, and Community Benefit Programs implemented by the hydrocarbon sector in Colombia" [17], in order to identify policy guidelines and available instruments actors have for management.

Regarding the specific obligations of the "General Methodology for the submission of Environmental Studies", that requires the submission of the "Environmental Alternatives Diagnostic"; and the "Environmental Impact Assessment" (EIA by its initials in Spanish). There should be an environmental characterization of the area of interest, identifying the areas of special management, as well at the characteristics of social and economic environment for each alternative presented. According to the NHA (National Hydrocarbons Agency) documents, Community Benefit Plans (PBC) are social investments to undertaken by companies engaged in the oil industry as part of the social responsibility policy. This happens in the context of contracts and agreements signed with the NHA in order to foster sustainable development in the implementation in the respective areas of influence, seeking community integration and contributing to the reduction of extreme poverty in Colombia [17].

\subsection{Ethnic groups, protected areas and land use management}

The General Census of 2005 counted 41,468,384 persons residing in Colombian territory, of which 5,709,238 recognized as persons belonging to an ethnic group. The indigenous population at $1,392,623$ people is $3.43 \%$ of the population of the country that provided information about their ethnicity; Afro-Colombians are 4,311,757 people which is $10.62 \%$ of the total population; Romi or Gypsy number 4,857, representing $0.01 \%$ of the total 
population. A total of $34,898,170$ people, representing $85.94 \%$ were not recognized as belonging to any of the ethnic groups [18].

These reservations of ethnic groups in their modern version created by resolution of the Colombian Institute for Rural Development (INCODER). Under the Constitutional Court ruling T-188 of 1993, Afro-Colombian communities can also protect their territory in areas called Collective Territories (TC), which, like the indigenous reserves, are large tracts of land mainly located in the region of Chocó. This population is sheltered under the classification of "Ethnic Groups," that, due to their minority status and increased vulnerability, have a particular regulatory framework. These territories also recognized as having an ecological function of property.

Finally, the characteristics of the country in terms of endemism and richness of its biodiversity, have led to the declaration of various levels of planning for the conservation of strategic ecosystems and species beginning from a system of protected areas including some of national, regional, and local.

The huge proportion of the country in which ethnic groups reside allows us the importance this has for the survival of these communities. The proper management of development projects to carry out in these territories has important cultural implications, as well as the impact of the arrival of foreign capital on the productive systems in a remote region separated from the social and economic dynamics of the rest of country. In light of this, Law 21 of 1991, require that the consultation to ethnics groups must take place before starting or authorizing any programs for the exploration or exploitation of natural resources in the territories of indigenous peoples and Afro-Colombian communities. In addition, given the diversity of ethnic groups in the country, it will be necessary to build a particular methodology for each consultation process according to the characteristics and peculiarities of the concerned population [19].

\section{METHODOLOGY}

For the elaboration of these indicators, a multivariable qualitative analysis was carried out under the case study methodology within the framework of ecosystem services. Initially, conventional methodologies were revised in the Environmental Impact Assessment (EIA) as the matrix of Conesa [4], that of Bergere Leopold et al. [5], and the proposed by Arboleda [6]. Once the first nuance built, an expert workshop held in Bogotá with representatives of public and private entities responsible for managing the issue at the national, regional, and local levels. In this workshop, the experts gave feedback on the proposed indicators, as well as on the criteria used to assess the impacts. They were organized in small groups according to their competences, and the printed matrices were delivered according to their topics of interest and management areas. They evaluated the variables according to whether they considered them relevant and the degree of importance that each variable would have in the general aspect was evaluated. The information that was collected in the expert workshop was used to reduce the indicators and reduce the nuance to those variables that could be fed with reliable information from secondary sources, and which in turn allowed for objective evaluation of the different aspects of the management of impacts of these types of projects. The main observation of those attending the workshop was the need to have an objective system, with standardized criteria and to not remain subject to the technician in charge of the study for environmental licensing.

Additionally, interviews were conducted with technicians from both companies and environmental authorities in the field; These interviews allowed for the deepening of the management needs of the agencies in charge of both companies and state entities with respect to the Management Plan and the Environmental License, as well as the ease of accessing 
specialized information in geographic viewers. In the interviews, we also consulted about the weighting of variables and components of the matrix of indicators required for the timely management of companies and environmental authorities. The main variables that should be considered were filtered, taking into account: (1) the requirements of the regulations that apply to these cases, both to employers and to the state entities involved; (2) elements of biodiversity and ecosystem services; and (3) evaluative elements of the social components with reliable information from secondary sources. It was then decided to rethink the indicators according to the needs of management of companies and environmental authorities, applied to the case and simplifying the matrix to the indicators that had sufficient information for each case and according to the requirements of License and Management Plan Environmental.

On the polygon facilitated by MOMPOS Oil Co. Inc., a socio-economic characterization of the area of influence was then made and, for the environmental determinants, coverage was available on official platforms. The following free access tools were identified, fed with official information from the competent government entities so that the blocks can be analysed with accurate information, even before environmental licensing processes.

\subsection{Calculation of indicators}

We worked on two components: biodiversity and ecosystem services, and social. Each indicator has the set of variables that relied on reliable information, under criteria that define the variable for its assessment. The variables are weighted according to their greater or lesser relevance, giving them a strategic value defined between 1 and 3. A higher relevance indicates a greater strategic value. The valuation of the variables is established in a range of 0 to 3, where: $\mathrm{LOW}=0, \mathrm{MEDIUM}=1, \mathrm{HIGH}=2$, and VERY HIGH $=3$. The resulting value of each variable is equal to the strategic value multiplied by the valuation as shown in eqn (1):

$$
V=E * W,
$$

- $\quad V$ is the resulting value of the variable;

- $E$ is the strategic value;

- $W$ is the valuation given to the variable.

Next, the resulting value of the indicator is calculated, which is equal to the sum of the resulting values of its variables, as shown in eqn (2):

$$
I=\sum R,
$$

- $\quad I$ is the resulting value of the indicator, equal to the sum of R;

- $R$ which is the resulting value of the variables.

Once the resulting values of the indicator and the variables have been calculated, the maximum value of the indicator (VMI) is calculated, as expressed in eqn (3). The VMI is obtained by multiplying the sum of the strategic values (E) by three (3) that would be the maximum rating (Very High):

$$
V M I=\left(\sum \mathrm{E}\right)^{*} 3 .
$$

Finally, the final weighting of the indicator is done in terms of percentage (\%), the maximum value of the indicator is taken as a reference of $100 \%$ and is related in percentage to the resulting value of the indicator. 


\section{RESULTS AND CONCLUSIONS}

\subsection{Characterization of the socio-ecological systems of the area of influence of the block}

The block is in jurisdiction of the municipalities of Piamonte and San Jose de Fragua in the department of Cauca as shown in Fig. 1, in an area of the country known as the "caucana boot". The municipality of Piamonte possesses important areas with forest cover and wildlife resources marking a biodiversity that makes it strategic. The mountains of the Churumbelos are perhaps the most important natural heritage sites of this region. The municipality has a large number of surface water sources, among which can be highlighted the watershed basin of the rivers Caqueta and Fragua, the sub-watershed of Tambor, Inchiyaco, Guayuyaco, Congor, and their microbasins. Currently there are more than 50,000 hectares of primary forest and over 70 water bodies with more than $1 \mathrm{~m} / \mathrm{sec} 1000 \mathrm{lps}$ [20]. For its part, San Jose del Fragua has areas of high biodiversity, such as the Alto Fragua Indi Wasi National Park (PNN), the Mountainous PNN of the Churumbelos and Cuevo de los Guacharos PNN, as well as the watershed basins of the Fragua Chorroso, San Pedro, Luna, Yurayaco, Fraguita, Sabaleta, and Fragua Grande rivers [21]. Approximately $47 \%$ of the total area of the municipality is under this level of conservation $(122,800$ hectares, total municipal extension according to EOT) [21].

The results of the latest study by the Institute Alexander Von Humboldt (IIAVH) were utilized for the ecological characterizations presented here, where units of territorial analysis (UAT) corresponding to the conservation coarse filter targets were defined and analysed according to a scale of 1:100,000. For this exercise hydro-biological information of biomes

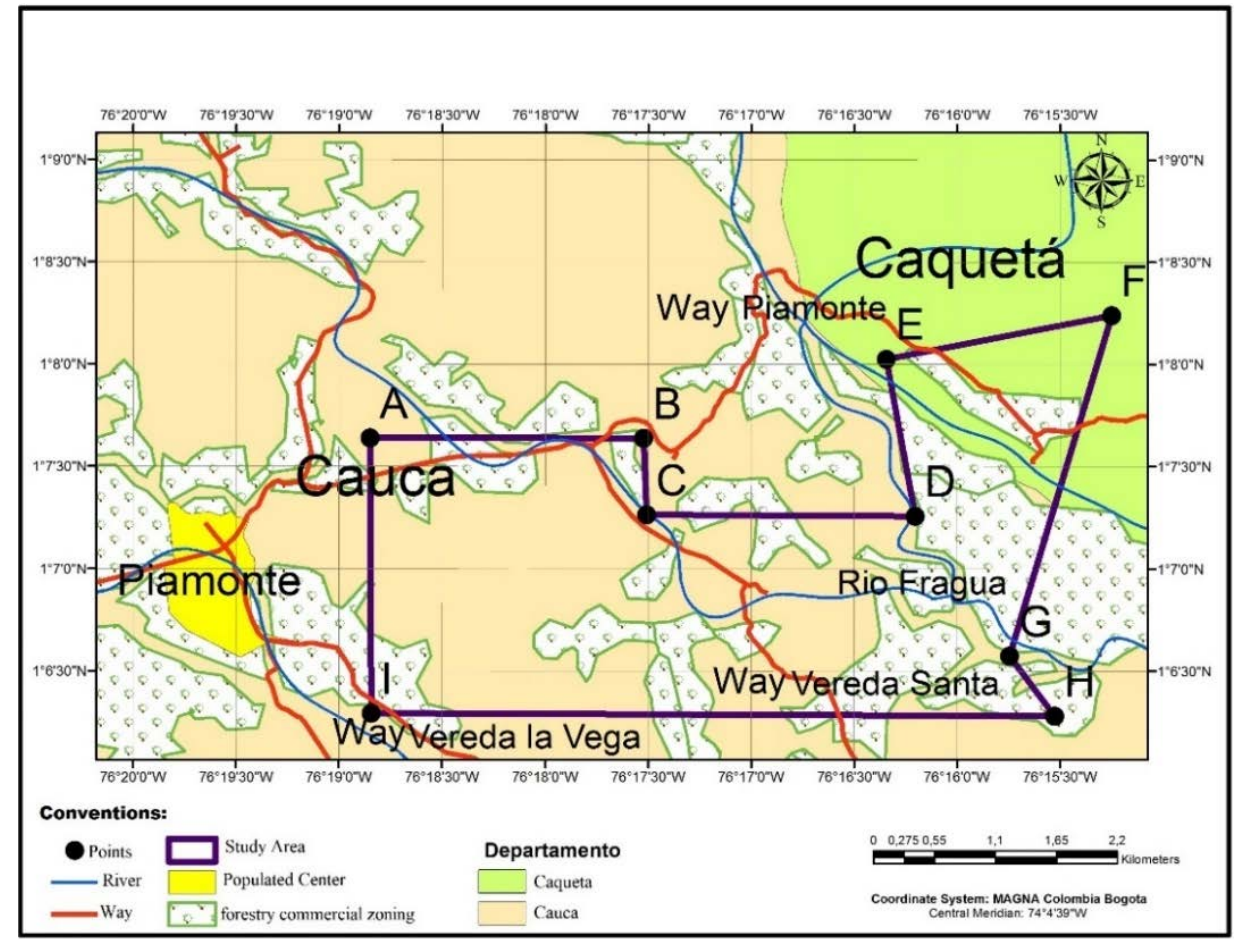

Figure 1: Map case study results, block PUT 1. 
and biogeography, both aquatic and terrestrial were included. Consequently, ecological, biological, and biogeographic processes, both terrestrial and aquatic that are distinctive to each region, are included in this UAT [9]. Therefore, the following results obtained from the analysis of the PUT 1 block as seen in Tables 1 and 2 .

With respect to the figures of land use management and planning, presence of ethnic groups and analysis of land use, the data in Table 2 shows us the results shown in Table 3.

The geographic information and data from secondary sources, allows us to observe that the polygon found outside what considered the areas of exclusion such as the protective forest reserves, protected areas, and portfolio of conservation priorities. However, its proximity to protected areas of national character and its importance in terms of vegetation coverage, water regulation and carbon storage as main ecosystem services generated by the area require special attention in management measures. In relation to the environmental determinants and the use of land, Fig. 1, allows us to identify the components to take into account in block PUT1, in order to generate the indicators.

3.2 Conclusions: guidelines for the management of impacts on the socio-ecological systems in areas of direct project influence

The compensation measures as “...actions aimed at compensating and giving back to communities, regions, localities, and the natural environment due to the impacts or negative effects generated by a project, work or activity, which cannot they can be avoided, corrected, mitigated or replaced". Table 4 shows the guidelines for managing impacts on development projects.

Table 1: Landscape units in PUT 1. (Source: Authors, with data from Institute of Research Alexander Von Humboldt.)

\begin{tabular}{|l|c|c|}
\hline Landscape unit & Hectares & \% in the block \\
\hline Humid Zonobiome in Florencia & 330 & $22 \%$ \\
\hline Humid Zonobiome of the Amazon foothills in Florencia & 72 & $5 \%$ \\
\hline Helobiome of the Amazon of Medio Caquetá & 1,097 & $73 \%$ \\
\hline Helobiome of the Amazon in Florencia & 4 & $0 \%$ \\
\hline TOTAL & 1,503 & $100 \%$ \\
\hline
\end{tabular}

Table 2: Environmental determinants for the environmental management of the shape. (Source: Authors, with data from the Institute of Research Alexander Von Humboldt.)

\begin{tabular}{|l|c|c|}
\hline Environmental determinants & Hectares & \% in the shape \\
\hline Strategic ecosystems & 72 & $5 \%$ \\
\hline Integrity (4) & 83 & $6 \%$ \\
\hline Integrity (2) & 151 & $10 \%$ \\
\hline Connectivity & 64 & $4 \%$ \\
\hline Water regulation & 1503 & $100 \%$ \\
\hline Wetland potential & 24 & $2 \%$ \\
\hline Carbon storage (3) & 427 & $28 \%$ \\
\hline Carbon storage (1) & 1075 & $72 \%$ \\
\hline Richness of species (2) & 1425 & $90 \%$ \\
\hline
\end{tabular}


Table 3: Land use management and planning. (Source: Authors, with data from the Institute of Research Alexander Von Humboldt, 2016.)

\begin{tabular}{|l|l|c|c|}
\hline \multirow{2}{*}{ Indicators } & Category & Hectares & \% of the block \\
\hline \multirow{4}{*}{ Forest reserves } & Law 2 forest reserves & 0 & $0 \%$ \\
\cline { 2 - 4 } & Law 53 (2) forest reserves & 17 & $1 \%$ \\
\cline { 2 - 4 } & Law 53 (1) forest reserves & 157 & $10 \%$ \\
\hline \multirow{4}{*}{ SINAP } & SPNN & 0 & $0 \%$ \\
\cline { 2 - 4 } & Priority portfolio (CONPES 3680) & 0 & $0 \%$ \\
\hline \multirow{5}{*}{ Land use } & Indigenous reservations & 0 & $0 \%$ \\
\cline { 2 - 4 } & TCCN & 0 & $0 \%$ \\
\cline { 2 - 4 } & Rural reserves & 0 & $0 \%$ \\
\hline & Cat 5 Land use reclassification & 72 & $5 \%$ \\
\cline { 2 - 4 } & Cat 4 Land use reclassification & 212 & $14 \%$ \\
\cline { 2 - 4 } & Cat 3 Land use reclassification & 1006 & $67 \%$ \\
\cline { 2 - 4 } & Productive systems (4) & 449 & $30 \%$ \\
\cline { 2 - 4 } & Productive systems (1) & 213 & $14 \%$ \\
\cline { 2 - 4 } & Conditioned areas (UATM 13) & 72 & $5 \%$ \\
\hline
\end{tabular}

Table 4: Proposed guidelines for managing impacts on development projects.

\begin{tabular}{|c|c|c|}
\hline Management measures & Elements for decision making & Management instrument \\
\hline Prevention & $\begin{array}{l}\text { Conservation priorities } \\
\text { Exclusion areas }\end{array}$ & Environmental license \\
\hline Mitigation and correction & $\begin{array}{l}\text { Expected impacts } \\
\text { Good practices }\end{array}$ & $\begin{array}{l}\text { Management and } \\
\text { environmental } \\
\text { monitoring plan }\end{array}$ \\
\hline \multirow{2}{*}{ Compensation measures } & $\begin{array}{l}\text { How much? } \\
\text { Compensation factors } \\
\text { Secondary vegetation: } \\
1 \text { ha }=[2-4 \text { ha }] \\
\text { Natural ecosystems: } \\
1 \text { ha }=[4-10 \text { ha }] \\
\end{array}$ & \multirow{2}{*}{$\begin{array}{l}\text { Compensation plan } \\
\text { Programs of benefit to } \\
\text { communities }\end{array}$} \\
\hline & $\begin{array}{l}\text { How? } \\
\text { Ecosystem equivalences } \\
\text { Priority areas for conservation } \\
\text { Priority areas for restoration } \\
\text { Where? } \\
\text { Conservation and restoration }\end{array}$ & \\
\hline
\end{tabular}

As a result of the different cartographic analyses applied to the study area, the information about de socioeconomic aspects and the consult to the experts, we propose the matrix of indicators in Table 5, for the management of impacts in the area of influence. The weighing of the variables includes expert opinions. You can find results graphically in Fig. 2 with the principal indicators that will be necessary in the environmental management. 
Table 5: Proposal of indicators of efficient management of impacts.

\begin{tabular}{|c|c|c|c|c|}
\hline Component & Indicators & Variables & Management measures & Value \\
\hline \multirow{8}{*}{$\begin{array}{l}\text { Biodiversity } \\
\text { and ecosystem } \\
\text { services }\end{array}$} & \multirow{5}{*}{ Protected areas } & National natural parks & \multirow{5}{*}{$\begin{array}{l}\text { Impact assessment } \\
\text { during licensing process } \\
\text { and exploration. } \\
\text { Monitoring during } \\
\text { management plan }\end{array}$} & \multirow{5}{*}{$25 \%$} \\
\hline & & $\begin{array}{l}\text { Regional District } \\
\text { Integrated Management } \\
\text { DRMI }\end{array}$ & & \\
\hline & & Forest reserves law 2 & & \\
\hline & & $\begin{array}{l}\text { Landworkers reserves } \\
\text { (RsCA) }\end{array}$ & & \\
\hline & & $\begin{array}{l}\text { Reservations Civil } \\
\text { Society (RsSC) }\end{array}$ & & \\
\hline & Species richness & $\begin{array}{l}\text { Relative wealth of } \\
\text { species }\end{array}$ & $\begin{array}{l}\text { Factors of compensation } \\
\text { secondary vegetation: } \\
1 \text { ha }=[2-4 \text { ha }] \\
\text { Natural ecosystems: } \\
1 \text { ha }=[4-10 \text { ha }]\end{array}$ & $67 \%$ \\
\hline & \multirow[b]{2}{*}{$\begin{array}{l}\text { Water and air } \\
\text { regulation }\end{array}$} & Water supply & \multirow{2}{*}{$\begin{array}{l}\text { Impact assessment } \\
\text { during licensing process } \\
\text { and exploration. } \\
\text { Monitoring during } \\
\text { management plan }\end{array}$} & \multirow[b]{2}{*}{$50 \%$} \\
\hline & & Carbon capture storage & & \\
\hline \multirow{6}{*}{$\begin{array}{l}\text { Socio- } \\
\text { economic } \\
\text { systems }\end{array}$} & \multirow{3}{*}{ Land use } & Agriculture & \multirow{3}{*}{$\begin{array}{l}\text { The purchase and the } \\
\text { restoration of the rights } \\
\text { of ownership of land will } \\
\text { be required }\end{array}$} & \multirow{3}{*}{$44 \%$} \\
\hline & & Livestock & & \\
\hline & & Rural & & \\
\hline & \multirow[b]{2}{*}{ Public order } & Actors in conflict & \multirow{2}{*}{$\begin{array}{l}\text { The company should } \\
\text { anticipate complications } \\
\text { and additional costs } \\
\text { generated by the actors } \\
\text { in the conflict }\end{array}$} & \multirow[b]{2}{*}{$67 \%$} \\
\hline & & Illegal activities & & \\
\hline & Ethnic groups & \begin{tabular}{|l} 
Indigenous communities \\
Black comunities
\end{tabular} & $\begin{array}{l}\text { Area of influence of } \\
\text { indigenous reserves }\end{array}$ & $50 \%$ \\
\hline
\end{tabular}

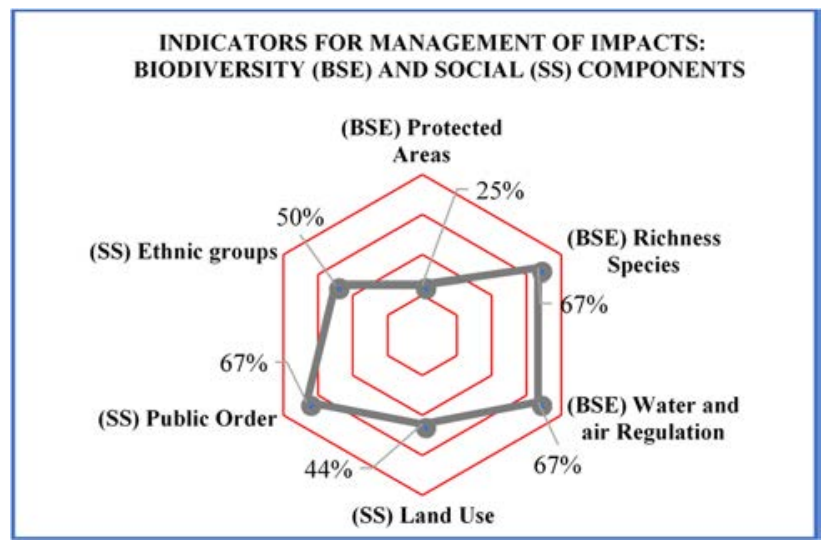

Figure 2: Indicators for the management of impacts. 


\subsection{Final matrix proposal for managing impacts on hydrocarbon projects}

Once the results of the analysis of the area of the polygon in the environmental and social determinants, taken account in the Licensing and Environmental Management Plan processes were obtained. The main indicators and variables available for each indicator were defined. According to the results of the analyses presented above, values of (0) Low, (1) Medium, (2) High, and (3) Very high were given, with respect to the area of the block that was in the variables defined from the data. Each variable within the indicators was weighted with values 1,2 , and 3, according to the relative importance of the variables in the indicator. The percentage distribution was made for each indicator separately, since each topic has its particular management measures. The proposed evaluations were consulted with Mompos technicians, technicians from the environmental authority, and a researcher from the Humboldt Institute in charge of this topic.

The indicators that come out with values higher than $60 \%$ considered of Very high impact for the management, so special care should be taken with those components of the Licensing and Management Plan. This proposal (Table 5) has been submitted to discussion with technicians from companies, environmental authorities, and academics working on this issue; it is certainly not definitive and it would be expected to refine the strategic values better from other cases on different polygons. According to the study, we can conclude that the main factors to take into account in this case, such as public order and species richness, will probably result in an increase in the costs that a company will have to assume in a frequently unexpected way. For loss of biological diversity and, probably, environmental education activities with workers would be required since many impacts on wildlife are caused by the increase in illegal hunting and traffic generated by the people in direct or indirect relation with the project. Applying this nuance to other polygons, it could be established more clearly a point that suggests to the employer when a project would be unfeasible.

The presence of ethnic groups in the area of influence will require prior consultation with the indigenous community because they are present in the area of influence. This component would probably imply an increase in the costs associated with social investment and programs with the community for the better development of the operation. This particularly affects the viability since the community of the area of influence at any time can block the operation to obtain some a result from the company and the government in office. In this sense, the prior consultation process has a minimum duration but not a maximum one, which affects the financial models.

The tool offers strategic advantages for decision makers, it allows the authorities to better delimit the areas offered in bids, taking into account the vulnerability. The companies can make better-informed decisions about their participation of the project. The system feedback allows updating the database with new findings during operations. Finally, it facilitates the monitoring by the environmental licensing authority (ANLA) and the assessment of the suitability of the management plans (PMA) proposed by the operating companies.

\section{ACKNOWLEDGEMENTS}

For the company Mompos Oil Co. Inc., Juan Carlos Buitrago and Valentin Alejandro de Mollinedo, for their important contributions in putting their point of view of companies for the analysis of information. To the students: María Paula Ortiz, Mónica T Herrera of the Semillero Economía y Ambiente, for her support in this research. To the experts who participated in the focal group. 


\section{REFERENCES}

[1] UPME, Indicadores de la mineria en Colombia-Version Preliminar, Unidad de Planeacion Minero Energetica - Subdireccion de Planeacion Minera: Bogotà DC, 2014.

[2] Zapata Pérez, D.M. \& Londoño Berrio, C.A., Metodología general para la presentación de estudios ambientales, Ministerio de Ambiente, Vivienda y Desarrollo Territorial: Bogotà DC, 2010.

[3] CEPAL, Indicadores ambientales y de desarrollo sostenible: avances y perspectivas para América Latina y el Caribe, América Latina y el Caribe: Santiago de Chile, 2007.

[4] Conesa, F.V., MUNDI-PRENSA, Guía Metodológica para la Evaluación de Impacto Ambiental: Madrid, 1993.

[5] Bergere Leopold, L., Eldridge Clarke, F., Balsley, J.R. \& Hanshaw, B.B., A Procedure for Evaluating Environmental Impact, U.S. Geological Survey: Washington, DC, 1971.

[6] Arboleda, J., Una propuesta para la identificación y evaluación de impactosmbientales. Rónica Forestal y del Medio Ambiente, 9, pp. 71-81, 1994.

[7] Quiroga Martínes, R., Indicadores ambientales y de desarrollo sostenible: avances y perspectivas para América Latina y el Caribe, Naciones Unidas: Santiago de Chile, 2007.

[8] ANH (Antecedes historicos). (Programa de regionalizacion, Sector Hidrocarburos), Programa de regionalización-Sector hidrocarburos, S.f., Online. www.anh.gov.co/ portalregionalizacion/Paginas/antecedentes-historicos.asp. Accessed on: 8 Mar. 2016.

[9] ANH, Indicadores \& Estrategias del Sector de Hidrocarburos, Agencia Nacional de Hidrocarburos-Colombia Genera: Bogotà, 2015.

[10] DPN, Plan Nacional de Desarrollo 2014-2018, Imprenta Nacional de Colombia: Bogotá DC, 2014.

[11] Reuters, Crudo vuelve y cae a niveles de 26,8 dólares el barril, El Tiempo, 11 Feb. 2016.

[12] Martínez, O.A., Impacto de un nuevo panorama de los precios del petroleo en las diferentes regiones de Colombia, Programa de las Naciones Unidas para el Desarrollo (PNUD), 2016.

[13] El Pais, Ecopetrol registró pérdidas de 3,9 billones de pesos en 2015, El Pais, Online. www.elpais.com.co/elpais/economia/noticias/ecopetrol-registro-perdidas-39-billones -pesos-2015. Accessed on: 9 Mar. 2016.

[14] ACP, Informe Económico No. 3, Vicepresidencia de Asuntos Económicos: Bogotà DC, 2016.

[15] MADS, Manual para la asignación de Compensaciones por Pérdidas de la Biodiversidad, Ministerio de Ambientey Desarrollo Sostenible (MADS), Autoridad Nacional de Licencias Ambientales (ANLA), The Nature Conservancy (TNC), World Wildlife Fund (WWF) y Conservación Internacional (CI): Bogotá DC, 2013.

[16] MAVDT, Términos de referencia Sector Hidrocarburos, Ministerio de Ambiente, Vivienda y Desarrollo Territorial: Bogotá DC, 2010.

[17] ANH y PNUD, Linea base:Programa en Beneficio de las comunidades implementados por el Sector de Hidrocarburos en Colombia, Editora 3 Ltda: Bogotà DC, 2013.

[18] DANE, Análisis Regional de los Prinicipales Indicadores Sociodemográficos de la Comunidad Afrocolombiana e Indígena a Partir de la Información del Censo General, 2005, Online. www.dane.gov.co/files/censo2005/etnia/sys/Afro_indicadores_socio demograficos_censo2005.pdf. Accessed on: 4 Apr. 2016. 
[19] RUNAP, Registro Único Nacional de Áreas Protegidas, Parques Nacionales Naturales de Colombia, 2015, Online. http://runap.parquesnacionales.gov.co/. Accessed on: 12 Apr. 2016.

[20] Alcaldia de Piamonte - CAUCA, Sitio oficial de PIAMONTE en CAUCA, Colombia, Online. http://piamonte-cauca.gov.co/indicadores_anuales.shtml?apc=bexx-1-\&x= 1632021\#poblacion. Accessed on: 18 May 2012.

[21] Alcaldia Municipal de San Jose del Fragua, Informacion General, Online. www.sanjosedelfragua-caqueta.gov.co/informacion_general.shtml\#historia. Accessed on: 6 Apr. 2016. 